\title{
OPTIMIZATION OF CNC OPERATING PARAMETERS TO MINIMIZE SURFACE ROUGHNESS OF Pinus sylvestris USING INTEGRATED ARTIFICIAL NEURAL NETWORK AND GENETIC ALGORITHM
}

\author{
Ayşenur Gürgen ${ }^{1, \diamond}$ \\ https://orcid.org/0000-0002-2263-7323 \\ Ali Çakmak ${ }^{1}$ \\ https://orcid.org/0000-0002-0827-022X \\ Sibel Yıldız ${ }^{1}$ \\ https://orcid.org/0000-0001-8448-4628 \\ Abdulkadir Malkoçoğlu ${ }^{1}$ \\ https://orcid.org/0000-0003-2416-5099
}

\begin{abstract}
The surface roughness of wood is affected by the processing conditions and the material structure. So, optimization of operation parameters is very crucial to have minimum surface roughness. In this study, modeling and optimization of surface roughness $\left(\mathrm{R}_{\mathrm{a}}\right)$ of Scotch pine (Pinus sylvestris) was investigated. Firstly, the samples were cut under different conditions $8 \mathrm{~mm}, 9 \mathrm{~mm}$ and $11 \mathrm{~mm}$ depth of cut and $12 \mathrm{~mm}, 14 \mathrm{~mm}$ and 16 $\mathrm{mm}$ axial depth of cut) in computer numerical control (CNC) machine, and then surface roughness $\left(\mathrm{R}_{\mathrm{a}}\right)$ values of samples were calculated. Then a prediction model of surface roughness was developed using artificial neural networks (ANN). Optimization process was carried out to reach minimum surface roughness of wood samples by the genetic algorithm (GA) method. MAPE value of the ANN model was found lower than 4,0\%. The optimum CNC operation parameters were 1874,5 rad/s, 3,0 m/min feed rate, 9,7 mm depth of cut and $12 \mathrm{~mm}$ for axial depth of cut for minimum surface roughness. As a result of study, surface roughness of Scotch pine wood can be modeled and optimized using integrated ANN and GA methods by saving time and cost.
\end{abstract}

Keywords: Artificial neural network, genetic algorithm, modeling, Pinus sylvestris, optimization, surface roughness.

\section{INTRODUCTION}

Surface roughness is a very small and periodic repetition of irregularities caused by the production methods used or the effects of processing factors (Peters and Cumming 1970). As a result of the method differences in the processing of wood and wood-based products with various machines and tools, surface roughness occurs in a wide range, which is very important to be measurable and controllable. When an adequate and homogeneous surface smoothness cannot be achieved, surface defects that become more pronounced after surface treatments adversely affect product quality and price (Hazır and Koç 2018, Tiryaki 2014). 
It was reported that anatomical properties such as, wood density, annual ring variation, latewood/earlywood ratio and cell structure of wood affect the surface roughness value of wood sample (Burdurlu et al. 2005, Kilic et al. 2006, Thoma et al. 2015). In addition, surface roughness of wood affected by cutting machine and cutting parameters. Researchers have been reported that machine parameters affect surface roughness of wood and wood-based materials (Gawroński 2013, Sutcu 2013, Koc et al. 2017). The anatomical properties of wood are not changeable, but the processing conditions can be adjusted to the desired range of operating parameters of the machine (Hazır and Koç 2019). Therefore, it is very important that the processing conditions are adjusted to minimize surface roughness.

The surface roughness is affected by the processing conditions and the material structure and also there is no mathematical formula to determine this parameter. In order to estimate the effect of variables in such problems, modeling studies are carried out. Studies have been conducted to predict the surface roughness of not only wood and wood-based products but also other materials. Comparison of some of these studies with this study was presented in Table 1 .

Table 1: Comparison of some surface roughness studies with this study.

\begin{tabular}{|c|c|c|c|}
\hline Previous study & Studied material & Independent variables & Method \\
\hline $\begin{array}{l}\text { Asilturk and Cunkas } \\
\text { (2011) }\end{array}$ & AISI 1040 steel & $\begin{array}{l}\text { Cutting speed, feed rate, } \\
\text { depth of cut }\end{array}$ & $\begin{array}{l}\text { ANN and multiple } \\
\text { regression (MR) }\end{array}$ \\
\hline $\begin{array}{l}\text { Prakash and } \\
\text { Palanikumar (2011) }\end{array}$ & $\begin{array}{l}\text { Medium density } \\
\text { fiberboards } \\
(\mathrm{MDF})\end{array}$ & $\begin{array}{l}\text { Spindle speed, feed rate, } \\
\text { Drill diameter }\end{array}$ & $\begin{array}{l}\text { Taguchi and } \\
\text { response surface } \\
\text { method (RSM) }\end{array}$ \\
\hline Patel et al. (2014) & Aluminum & $\begin{array}{l}\text { Spindle speed, feed rate, } \\
\text { depth of cut }\end{array}$ & $\mathrm{ANN}$ \\
\hline Tiryaki et al. (2014) & $\begin{array}{l}\text { Beech wood } \\
\text { Spruce wood }\end{array}$ & $\begin{array}{l}\text { Wood species, feed rate } \\
\text { cutting depth, annual } \\
\text { ring, number of cutter, } \\
\text { grain size of abrasives }\end{array}$ & ANN \\
\hline $\begin{array}{l}\text { Kant and Sangwan } \\
(2015)\end{array}$ & AISI 1060 steel & $\begin{array}{l}\text { Cutting speed, feed rate, } \\
\text { depth of cut, flank wear }\end{array}$ & ANN, GA \\
\hline Sofuoglu (2015a) & $\begin{array}{l}\text { Massive wooden } \\
\text { edge-glued } \\
\text { panels of Pinus } \\
\text { sylvestris L. }\end{array}$ & $\begin{array}{l}\text { Cutter type, tool } \\
\text { clearance } \\
\text { spindle speed, feed rate, } \\
\text { depth of cut }\end{array}$ & ANN \\
\hline $\begin{array}{l}\text { Stanojevic et al. } \\
(2017)\end{array}$ & $\begin{array}{l}\text { Pedunculate oak } \\
\text { (Quercus robur } \\
\text { L.) wood }\end{array}$ & $\begin{array}{l}\text { Feed rate, cutting depth, } \\
\text { rake angle }\end{array}$ & Neuro-fuzzy method \\
\hline Kumar (2018) & $\begin{array}{l}\text { C360 Copper } \\
\text { alloy }\end{array}$ & $\begin{array}{l}\text { Spindle speed, feed rate, } \\
\text { cutter of size }\end{array}$ & Regression, GA \\
\hline $\begin{array}{l}\text { Hazir and Ozcan } \\
(2019)\end{array}$ & $\begin{array}{l}\text { Beech (Fagus } \\
\text { orientalis } \\
\text { Lipsky) species }\end{array}$ & $\begin{array}{l}\text { Spindle speed, feed rate, } \\
\text { tool radius and depth of } \\
\text { cut }\end{array}$ & $\begin{array}{l}\text { Response surface } \\
\text { method (RSM), } \\
\text { desirability function } \\
\text { (DF) and genetic } \\
\text { algorithm (GA) }\end{array}$ \\
\hline This study & $\begin{array}{l}\text { Pinus sylvestris } \\
\text { L. wood }\end{array}$ & $\begin{array}{l}\text { Spindle speed, feed rate, } \\
\text { depth of cut, axial depth } \\
\text { of cut }\end{array}$ & ANN, GA \\
\hline
\end{tabular}

Asilturk and Cunkas (2011) compared the prediction ability of ANN and multiple regression (MR) methods. They investigated to estimate surface roughness of AISI 1040 steel in turning operations and reported that the ANN can predict more accurate the values than MR method.

Prakash and Palanikumar (2011) used taguchi and response surface method (RSM) to optimize the surface roughness of medium density board (MDF). They stated that feed rate was the parameter that most affects the surface roughness of MDF. Also, they indicated that estimated values of created model were very close to real values.

Patel et al. (2014) studied the surface roughness of aluminum cutting in CNC milling machine with different cutting conditions such as spindle speed, feed rate, and depth of cut. They implemented the ANN method to predict surface roughness and stated that ANN method gave better and nearest result (it can be predicted $91,94 \%$ accurate). 
Tiryaki et al. (2014) used ANN method to estimate surface roughness of beech and spruce wood. Wood species, feed rate, cutting depth, annual ring, number of cutter and grain size of abrasives were used as input parameters. As a result, they reported that surface roughness increased with increasing depth of cut and feed rate.

Kant and Sangwan (2015) colligated the ANN and GA methods to predict and optimize minimum surface roughness of AISI 1060 steel. They confirmed that prediction model obtained from ANN is fulfilling good statistically.

Sofuoglu (2015a) investigated to the surface roughness of massive wooden edge-glued panels of Pinus sylvestris with ANN method. Researcher used cutter type, tool clearance strategy, spindle speed, feed rate, and depth of cut as independent variables for ANN. At the ends of the study, it was reported that ANN method can be used to estimate the surface roughness.

Stanojevic et al. (2017) integrated the fuzzy inference system and ANN (called neuro-fuzzy method) to reach the minimum surface roughness and power consumption values of pedunculate oak (Quercus robur) wood machining different conditions. They stated that the euro-fuzzy method can be used successfully to minimize the surface roughness of wood and power consumption.

Kumar (2018) investigated that optimization of C360 Copper alloy material's surface roughness and machining time parameters in micro end milling. Researcher firstly obtained a model using regression techniques and optimized, using GA. Finally, it was reported that GA can be optimized the surface roughness in allowable rate $(10 \%)$.

Hazir and Ozcan (2019) combined three different methods: Response surface method (RSM), desirability function (DF) and genetic algorithm (GA) to predict surface roughness of beech samples. As a result of study, they reported that GA is appropriate to optimization of surface roughness of wood.

When all previous studies are examined, it is clear that methods such as ANN, GA can be used to model and optimize surface roughness. This study consisted of three steps. Firstly, experimental studies were carried out to determine the effect of the operational parameters of the CNC machine on the surface roughness of Scotch pine (Pinus sylvestris) wood. Secondly, a surface roughness prediction model was developed with ANN method. Thirdly, the operation parameters that affect the surface roughness of Scotch pine wood were optimized with GA method.

\section{MATERIALS AND METHODS}

\section{Experimental study}

In this study, Scotch pine (Pinus sylvestris L.) wood which widely used at forest industry was chosen as studied material. The preparation of the test samples was carried out according to principles of ASTM D 166687 (1994). The wood samples without any defects were chosen and prepared for experimental studies. Firstly, moisture content of wood samples was determined as $10 \%$ in accordance with TS 2471 (2005). The specimens were cut on a 3 axis CNC routing machine (AES Nova 2128) on across the grain direction with polycrystalline diamond (PCD) tool of $11 \mathrm{~mm}$ diameter.

Selected machining parameters were indicated in Table 2. 
Table 2: Experimental design of this study.

\begin{tabular}{|c|c|c|c|c|}
\hline \multirow{2}{*}{\multicolumn{2}{|c|}{ Machining parameters }} & \multicolumn{3}{|c|}{ Levels } \\
\hline & & 1 & 2 & 3 \\
\hline \multicolumn{2}{|c|}{ Spindle speed $(\mathrm{rad} / \mathrm{s})$} & 1257 & 1676 & 1885 \\
\hline \multicolumn{2}{|l|}{ Feed rate $(\mathrm{m} / \mathrm{min})$} & 2 & 4 & 6 \\
\hline Depth of cut (mm) & $\mathrm{a} / \mathrm{h}$ & 8 & 9 & 11 \\
\hline Axial depth of cut (mm) & $a_{p}$ & 12 & 14 & 16 \\
\hline
\end{tabular}

\section{Determination of surface roughness}

The surface roughness of samples was measured on across the grain direction using Mitutoyo Sj-301 (Peters and Cumming 1970). During the measurements, operations have been set as follows; speed of machine $0,5 \mathrm{~mm} / \mathrm{s}$, pick-up length $(\lambda \mathrm{c})$ of $2,5 \mathrm{~mm}$, stylus tip radius of $5 \mu \mathrm{m}$ and the stylus tip angle of $90^{\circ}$ (Bonac 1979). The surface roughness values were determined by a sensitivity of $\pm 0,01 \mu \mathrm{m}$. Arithmetic mean of profile deviations (Ra) was used for roughness measurements of the samples. All these measurements also complied with the principles of DIN 4768 (1990) standard.

\section{Modelling of surface roughness}

Artificial intelligence may consist of one or more of the methods such as intuitive, heuristic, neural, statistical and fuzzy logic used to model the problem in which the relationship between the inputs and outputs of any problem cannot be mathematically modeled. In general, ANN can be defined as a system designed to model the method of performing a function of the brain. In accordance with the brain's information processing method, ANN is a processor capable of storing and generalizing information after a learning process. The ANN is composed of various artificial nerve cells connected to each other and is usually arranged in layers (Haykin 1994). These layers can be generalized as input layer, hidden layer and output layer. The data affecting the target parameter creates the input parameters. The hidden layer is the layer in which information is processed according to the specified activation function. The determination of hidden neuron number is one of the important factors in the performance of the network. The output layer consists of the dependent variables of the problem.

ANN predicts the output parameters by continuously updating the weights between layers in network. ANN creates the predicted output according to Equation 1:

$$
\text { Output }_{k}=f_{2}\left(w_{0 k}+\sum_{j=1}^{m} w_{j k}\left[f_{1}\left(w_{0 j}+\sum_{i=1}^{n} \text { input }_{i} w_{i j}\right)\right]\right)
$$

Where, $\mathrm{i}=(1,2,3 \ldots, \mathrm{n}) ; \mathrm{j}=(1,2,3 \ldots, \mathrm{m}) ; \mathrm{k}=(1,2,3 \ldots, \mathrm{p})$, input ${ }_{i}$ is the value of the $\mathrm{i}^{\text {th }}$ input, $n$ is the number of input parameter, $w_{i j}$ is the weight between the input neurons and the hidden neurons, $w_{0 j}$ bias weight of hidden layer, $w_{j k}$ is the weight between the hidden and the output neurons, $m$ is the number of neurons of the hidden layer, $p$ is the number of neurons of the output layer, $w_{0 k}$ is bias weight of output layer and $f_{1}$ and $f_{2}$ is activation function.

The training process of ANN involves constantly updating the weights between layers to reach an optimum value. Optimization of the weights is carried out by learning optimization algorithms such as Levenberg-Marquardt (LM), Resilient Backpropagation (RB) and Scaled Conjugate Gradient (SCG) etc. The performance of any network is determined by various performance functions.

In this study, the ANN which is one of the techniques of artificial intelligence was used to predict the surface roughness. Spindle speed, feed rate, depth of cut and axial depth of cut were used as input parameters and surface roughness was used as output parameter. The structure of the network was shown in Figure 1. 


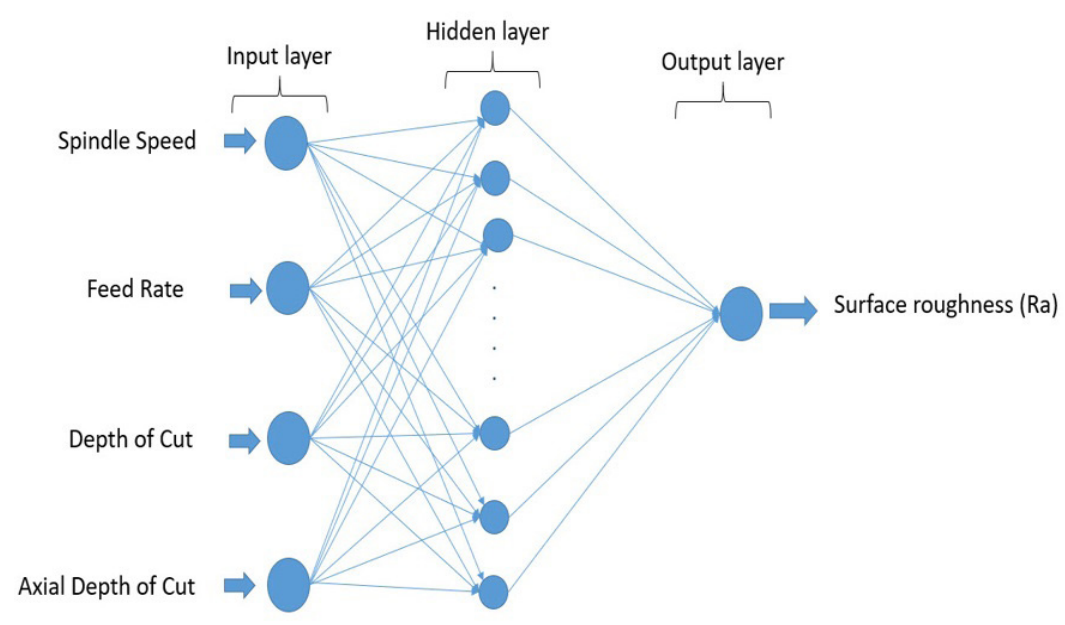

Figure 1: The simple structure of ANN model.

The data obtained from experimental studies were randomly divided into three sections: $80 \%$ of the data were used for training, $10 \%$ for validation, and $10 \%$ for testing. Two different training algorithms including LM and SCG were tried to optimum model.

Mean Square Error (MSE) was used as performance function of network and Mean Absolute Percentage Error (MAPE) was calculated to determine the prediction performance of network defined as Equation 2 and Equation 3, respectively.

$$
\begin{aligned}
& M S E=\frac{1}{n} \sum_{i=1}^{n}\left(e_{i}-p_{i}\right)^{2} \\
& M A P E=\frac{1}{n} \sum\left|\frac{e_{i}-p_{i}}{e_{i}}\right| \times 100
\end{aligned}
$$

Where, $e$ is the experimental result, $p$ is the prediction result, and is the number of samples.

Number of hidden layers was chosen one layer since the single hidden layer is sufficient for many complex engineering problem solutions. Determining the number of hidden neurons in this layer is an important process affecting the performance of the network. The high number of hidden neurons increases the complexity of the network and may also reduce the generalization ability of the network. That's way, the maximum number hidden neurons was set to 15 . Logistic sigmoid and linear transfer functions were used for hidden layer activation function and output layer activation function, respectively. The performance target of the model that stopped the training stage was considered to be $10^{-6}$. Maximum number of epochs was selected as 2000 epochs. Validation check was set to 50 .

\section{Optimization of CNC operation parameters}

The optimization process is a vital step for many engineering problems. Classical mathematical methods are insufficient for problems in which the mathematical model is complex and the number of decision variables is high. Heuristic algorithms have been developed to overcome this shortcoming. The most popular metaheuristic algorithm is the GA. 
GA is an optimization method that works in a way similar to the evolutionary process observed in nature. GA simulate the evolutionary process in a computer environment to optimization of complex engineering problems. First of all, an initial population containing chromosomes must be created for the optimization process. These chromosomes represent possible solutions of the problem. Crossing and mutation are the procedures performed on chromosomes representing possible solutions. New generations are obtained by passing selected individuals through genetic operators such as crossover and mutation (Mirjalili 2015).

In this study, GA method was used to optimize the operational parameters to find minimal surface roughness value. The optimization procedure can be expressed in the following:

Decision variables: $\mathrm{S}_{\mathrm{s},} \mathrm{F}_{\mathrm{r}}, \mathrm{D}_{\mathrm{c}}, \mathrm{D}_{\mathrm{ac}}$

Objective function : Minimum $\mathrm{R}_{\mathrm{a}}\left(\mathrm{S}_{\mathrm{s},} \mathrm{F}_{\mathrm{r}}, \mathrm{D}_{\mathrm{c},}, \mathrm{D}_{\mathrm{ac}}\right)$

Boundaries of decision variables:

$1257 \mathrm{rad} / \mathrm{s} \leq \mathrm{S}_{\mathrm{s}} \leq 1885 \mathrm{rad} / \mathrm{s}$

$\mathrm{m} / \min \leq \mathrm{F}_{\mathrm{r}} \leq 6 \mathrm{~m} / \mathrm{min}$

$8 \mathrm{~mm} \leq \mathrm{D}_{\mathrm{c}} \leq 11 \mathrm{~mm}$

$12 \mathrm{~mm} \leq \mathrm{D}_{\text {ac }} \leq 16 \mathrm{~mm}$

GA architecture were presented in Table 3. Population size was chosen 20 and roulette technique was used as selection method. One crossover point operator and 0,95 crossover rate were implemented to create new generation. Mutation rate which allows genetic variation were taken as 0,05 . Iteration number which is maximum generation number was set to 100. In addition, 21 runs carried out to evaluate the optimization algorithm performance.

Table 3: Genetic algorithm architecture.

\begin{tabular}{|c|c|}
\hline Parameters & Value \\
\hline Population size & 20 \\
\hline Iteration number & 100 \\
\hline Crossover rate & 0,95 \\
\hline Mutation rate & 0,05 \\
\hline Run number (optimization study) & 21 \\
\hline
\end{tabular}

This study consisted of three stages: experimental study, modeling and optimization and the flow-chart of study was presented in Figure 2.

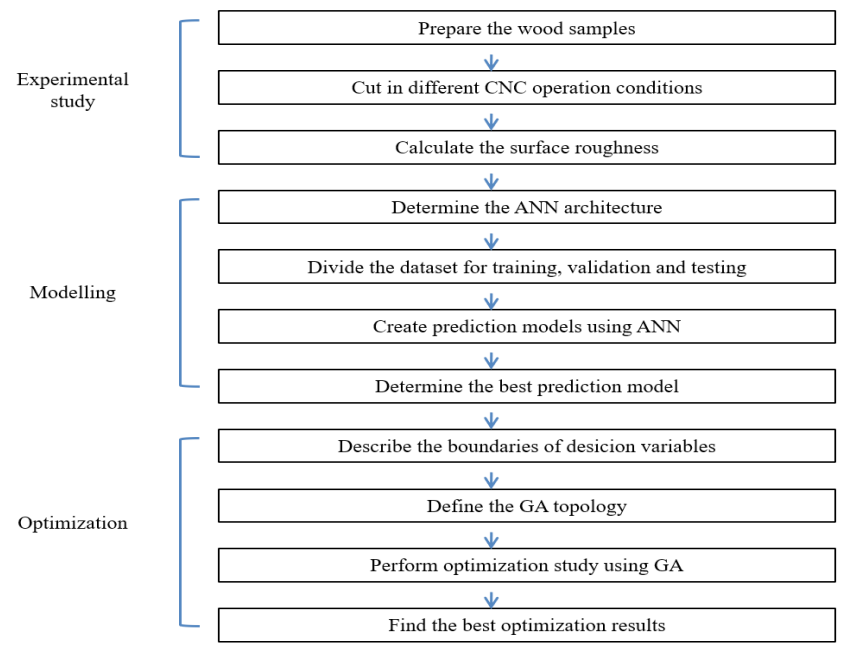

Figure 2: The flow-chart of this study. 


\section{RESULTS AND DISCUSSION}

\section{Experimental studies}

Surface roughness of Scotch pine wood samples after different machining were presented at Table 4.

As seen in Table 4, surface roughness value decreased with increasing speed for all machining parameters. Surface roughness value decreased with decreasing feed rate. When effect of depth to surface roughness cut evaluated, the maximum surface roughness value was determined the highest depth of cut. The minimum surface roughness was calculated at $9 \mathrm{~mm}$ axial depth of cut, the higher value was determined at $8 \mathrm{~mm}$ and 11 mm axial depth of cut, respectively.

Table 4: Surface roughness of Scotch pine wood samples.

\begin{tabular}{|c|c|c|c|c|}
\hline \multirow{2}{*}{\multicolumn{2}{|c|}{$\begin{array}{c}\text { Axial Doc (mm) } \\
\text { Doc (mm) }\end{array}$}} & \multicolumn{3}{|c|}{12} \\
\hline & & 8 & 9 & 11 \\
\hline$\underset{(\mathrm{m} / \mathrm{min})}{\mathrm{F}_{\mathrm{r}}}$ & $\underset{(\mathrm{rd} / \mathrm{s})}{\mathrm{S}_{\mathrm{S}}}$ & $\begin{array}{c}\mathrm{R}_{\mathrm{a}} \\
(\mathrm{um})\end{array}$ & $\begin{array}{c}\mathrm{R}_{\mathrm{a}} \\
(\mu \mathrm{m})\end{array}$ & $\begin{array}{c}\mathrm{R}_{\mathrm{a}} \\
(\mathrm{m})\end{array}$ \\
\hline 2 & 1257 & 6,16 & 5,6 & 8,11 \\
\hline 2 & 1676 & 5,53 & 5,29 & 8,02 \\
\hline 2 & 1885 & 4,99 & 4,67 & 7,46 \\
\hline 4 & 1257 & 9,26 & 6,18 & 11,80 \\
\hline 4 & 1676 & 9,10 & 6,12 & 11,57 \\
\hline 4 & 1885 & 8,88 & 5,83 & 10,97 \\
\hline 6 & 1257 & 10,01 & 8,09 & 10,82 \\
\hline 6 & 1676 & 9,82 & 6,58 & 10,36 \\
\hline 6 & 1885 & 9,46 & 6,24 & 9998 \\
\hline \multicolumn{2}{|c|}{ Axial Doc (mm) } & \multicolumn{3}{|c|}{14} \\
\hline \multicolumn{2}{|c|}{ Doc (mm) } & 8 & 9 & 11 \\
\hline$\underset{(\mathrm{m} / \mathrm{min})}{\mathrm{F}_{\mathrm{r}}}$ & $\begin{array}{c}\mathrm{S}_{\mathrm{s}} \\
(\mathrm{rad} / \mathrm{s})\end{array}$ & $\begin{array}{c}\mathrm{R}_{\mathrm{a}} \\
(\mu \mathrm{m})\end{array}$ & $\begin{array}{c}\mathrm{R}_{\mathrm{a}} \\
(\mu \mathrm{m})\end{array}$ & $\begin{array}{c}\mathrm{R}_{\mathrm{a}} \\
(\mu \mathrm{m})\end{array}$ \\
\hline 2 & 1257 & 9,72 & 7,31 & 11,75 \\
\hline 2 & 1676 & 9,53 & 6,58 & 11,44 \\
\hline 2 & 1885 & 7,42 & 6,16 & 10,89 \\
\hline 4 & 1257 & 9,94 & 6,44 & 12,72 \\
\hline 4 & 1676 & 8,24 & 6,06 & 12,55 \\
\hline 4 & 1885 & 8,49 & 5,84 & 12,40 \\
\hline 6 & 1257 & 11,17 & 8,84 & 11,44 \\
\hline 6 & 1676 & 10,96 & 7,98 & 9,47 \\
\hline 6 & 1885 & 11,07 & 7,18 & 8,79 \\
\hline \multicolumn{2}{|c|}{ Axial Doc (mm) } & \multicolumn{3}{|c|}{16} \\
\hline \multicolumn{2}{|c|}{ Doc (mm) } & 8 & 9 & 11 \\
\hline $\begin{array}{c}\mathrm{F}_{\mathrm{r}} \\
(\mathrm{m} / \mathrm{min})\end{array}$ & $\begin{array}{c}\mathrm{S}_{\mathrm{s}} \\
(\mathrm{rad} / \mathrm{s})\end{array}$ & $\begin{array}{c}\mathrm{R}_{\mathrm{a}} \\
(\mu \mathrm{m})\end{array}$ & $\begin{array}{c}\mathrm{R}_{\mathrm{a}} \\
(\mu \mathrm{m})\end{array}$ & $\begin{array}{c}\mathrm{R}_{\mathrm{a}} \\
(\mu \mathrm{m})\end{array}$ \\
\hline 2 & 1257 & 11,12 & 7,48 & 18,91 \\
\hline 2 & 1676 & 10,1 & 7,42 & 12,90 \\
\hline 2 & 1885 & 8,08 & 7,39 & 12,75 \\
\hline 4 & 1257 & 10,98 & 7,86 & 13,69 \\
\hline 4 & 1676 & 8,82 & 7,46 & 13,47 \\
\hline 4 & 1885 & 8,45 & 8,29 & 13,40 \\
\hline 6 & 1257 & 13,02 & 10,36 & 13,74 \\
\hline 6 & 1676 & 12,69 & 9,51 & 12,73 \\
\hline 6 & 1885 & 11,65 & 8,04 & 12,70 \\
\hline
\end{tabular}

There are some studies which were investigated to minimize surface roughness of wood or wood-based materials and the literature findings support our results. For example, De Deus et al. (2015) were stated that smoother surface of medium density board was obtained at $2 \mathrm{~m} / \mathrm{min}$ feed rate, $1 \mathrm{~mm}$ and $1,5 \mathrm{~mm}$ depth of cut, $1257 \mathrm{rad} / \mathrm{s}$ and $1676 \mathrm{rad} / \mathrm{s}$ spindle speed. Sofuoglu (2015b) investigated optimal machining parameters 
(spindle speed: $837 \mathrm{rad} / \mathrm{s}, 1257 \mathrm{rad} / \mathrm{s}$ and $1676 \mathrm{rad} / \mathrm{s}$, feed rate: $1 \mathrm{~m} / \mathrm{min}, 1,5 \mathrm{~m} / \mathrm{min}$ and $2 \mathrm{~m} / \mathrm{min}$, depth of cut: 4 $\mathrm{mm}$ ) of massive wooden edge-glued panels made of European larch (Larix decidua Mill.). The researcher notified that the lowest surface roughness was obtained at $1676 \mathrm{rad} / \mathrm{s}$ spindle speed and $2 \mathrm{~m} / \mathrm{min}$ feed rate. Hazir and Koc (2016) reported that the minimum surface roughness of Pinus nigra wood samples was determined at $1885 \mathrm{rad} / \mathrm{s}$ spindle speed, $2 \mathrm{~m} / \mathrm{min}$ feed rate and 2,6 $\mathrm{mm}$ depth of cut.

\section{Modelling of surface roughness}

In the present study, surface roughness of Scotch pine samples cut in different $\mathrm{CNC}$ routing conditions were modeled using ANN.

Two different learning algorithms and 15 hidden neurons (from 1 to 15) were tried to find the best model. The best ANN model was found using SCG algorithm. The number of hidden neurons of the best network can vary for each problem. In the studies performed to model of surface roughness of different materials, the optimum network was found as 5-5-1 network (Sofuoglu 2015a) for massive wooden edge-glued panels and 4-9-1 network for AISI 1060 steel (Kant and Sangwan 2015). In our study, the best model was obtained from 3-7-1 network for Scotch pine wood samples. The performance values including MSE and MAPE values of training, validation, test and all values for two models were presented in Table 5.

Table 5: Performance of best models.

\begin{tabular}{|c|c|c|c|c|}
\hline Performance & Training & Validation & Test & All \\
\hline MSE & 0,189 & 0,293 & 0,205 & 0,207 \\
\hline MAPE & 3,758 & 4,903 & 3,343 & 3,866 \\
\hline
\end{tabular}

MSE values of the were determined as 0,$189 ; 0,293 ; 0,205$ for training, validation and test of network, respectively. It is clear that MSE values are satisfactory for accurate of models.

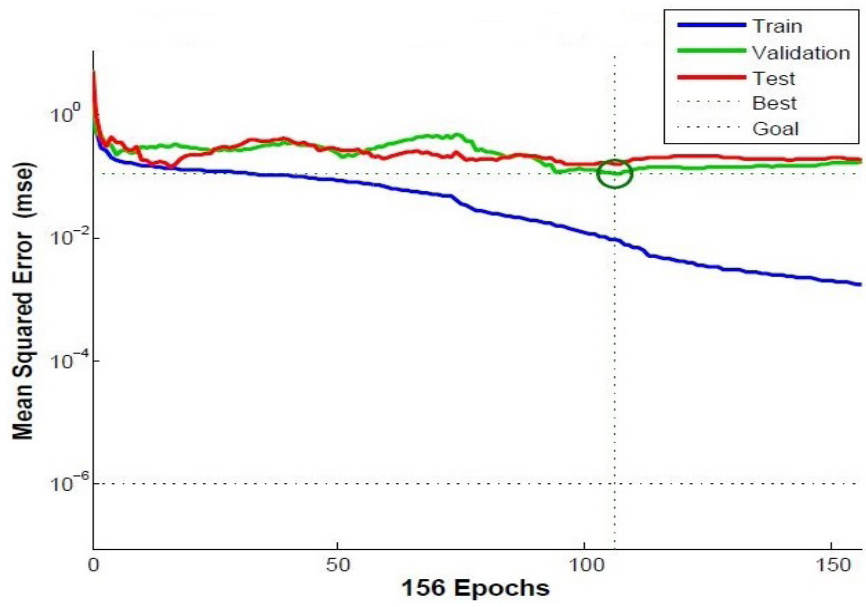

Figure 3: Performance of ANN model.

The value of MAPE is one of the values that measure the ability of the network to predict correctly. This ability of each created network may be different depending on the type of problem. MAPE values of artificial networks which estimate the surface roughness of different materials under different machining conditions were reported as 8,06 for aluminum Patel et al. (2014) and 20,18 for massive wooden edge-glued panels (Sofuoglu 2015a). In this study, MAPE values of all values were calculated as 3,866 for the best model. It means that that the prediction capability of the model is high. Performance of ANN model for Scotch pine was shown in Figure 3. 
Figure 3 shows the change in the MSE values of the data sets according to the number of epochs. After the 106 epoch, the error value (MSE) of the validation data set is continuously increasing and the training process is terminated in the 106th epoch. Best validation performance is determined 0,10859 at epoch 106.

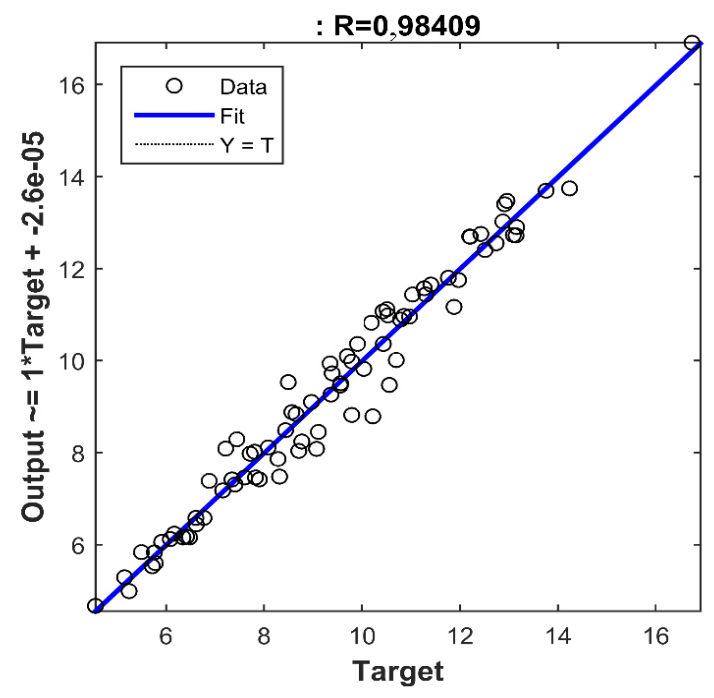

Figure 4: Regression plot of ANN model.

The correlation coefficients (R) was the other performance indicator of ANN model and regression plot was shown in Figure 4.

$\mathrm{R}$ value represents the correlation between the predicted and experimental values. The maximum value of $\mathrm{R}$ is 1 and if this value is close to 1,0 , the accuracy of the model is increases. $\mathrm{R}$ values of recommended network to predict surface roughness value in the literature were reported as 0,988 for massive wood Tiryaki et al. (2014). In this study, R was found as 0,98409 for Scotch pine wood samples.

\section{Optimization of CNC operating parameters}

An objective function is needed to optimize any problem. This objective function can be achieved by various modeling techniques like regression, ANN etc. In this study, the objective function is surface roughness and the model of surface roughness was obtained using ANN as mentioned above section.

In order to find the minimum surface roughness for Scotch pine wood samples, 21 simulations were carried out. Performance values of GA optimization method was given in Table 6.

Table 6: Performance of GA.

\begin{tabular}{|c|c|c|c|}
\hline \multicolumn{4}{|c|}{ Obtained Ra value of optimization studies $(\mu \mathrm{m})$} \\
\hline Minimum & Maximum & Mean & Standard deviation \\
\hline 3,8314 & 4,6484 & 4,2992 & 0,1954 \\
\hline
\end{tabular}

The performance of the optimization algorithm was measured based on the minimum, maximum, mean and standard deviations of the Ra values obtained by the GA algorithm. If the standard deviation of any model is low means that the results are more consistent. In this study, standard deviation of optimization algorithm was calculated as 0,1954 for Scotch pine wood samples. 
The minimum surface roughness values were found by the optimization algorithm and the machining parameters required to achieve these values are given in the Table 7.

Table 7: Operational parameter and Ra after optimization.

\begin{tabular}{|c|c|c|c|c|}
\hline $\begin{array}{c}\text { Objective value } \\
\begin{array}{c}\text { Ra value } \\
(\mu \mathrm{m})\end{array}\end{array}$ & $\begin{array}{c}\text { Spindle } \\
\text { speed }(\mathrm{rad} / \mathrm{s})\end{array}$ & $\begin{array}{c}\text { Feed rate } \\
(\mathrm{m} / \mathrm{min})\end{array}$ & $\begin{array}{c}\text { Depth of cut } \\
(\mathrm{mm})\end{array}$ & $\begin{array}{c}\text { Axial depth of } \\
\text { cut }(\mathrm{mm})\end{array}$ \\
\hline 3,8314 & 1874,5 & 3,0 & 9,7 & 12,0 \\
\hline
\end{tabular}

In current study, experimental studies were performed between $12571885 \mathrm{rad} / \mathrm{s}$ and $1885 \mathrm{rad} / \mathrm{s}$ speed, between $2 \mathrm{~m} / \mathrm{min}$ and $6 \mathrm{~m} / \mathrm{min}$ feed rate, between $8 \mathrm{~mm}$ and $11 \mathrm{~mm}$ depth of cut and, between $12 \mathrm{~mm}$ and 16 $\mathrm{mm}$ axial depth of cut. Spindle speed for the minimum surface roughness of Scotch pine wood samples was found as $1874,5 \mathrm{rad} / \mathrm{s}$. The optimum feed rates was $3,0 \mathrm{~m} / \mathrm{min}$. The optimum depth of cut and axial depth of cut were $9,7 \mathrm{~mm}$ and $12,0 \mathrm{~mm}$ for Scotch pine wood sample, respectively.

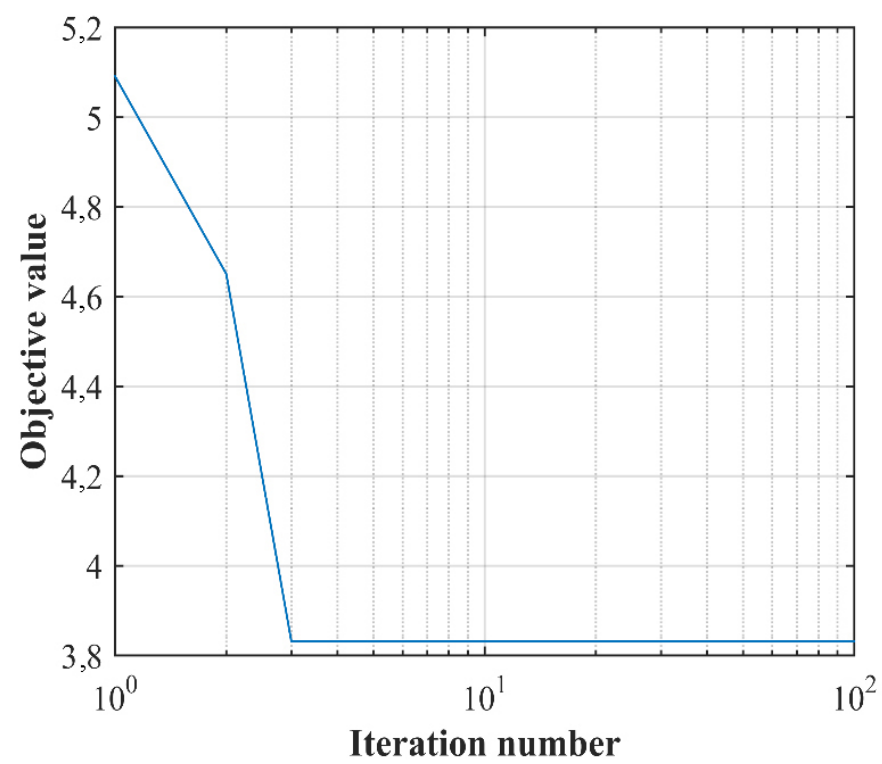

Figure 5: Optimization course for surface roughness.

Figure 5 displayed the optimization course for surface roughness of Scotch pine wood samples in logarithmic scale.

The objective value for the first generation was found to be $5,0915 \mu \mathrm{m}$. As the optimization process progressed with the formation of new generations, this value decreased and finally reached $3,8314 \mu \mathrm{m}$. In addition, Figure 5 showed that the number of iterations is sufficient to complete the search process.

\section{CONCLUSIONS}

Wood material is the most environmentally friendly among the building materials, and it is the warm due to its nature and only renewable resource. The use of wood began with the existence of humanity, and wood serves more and more purposes in human life day by day. The minimum surface roughness that occurs during wood processing is very important for other processing steps and is still not a fully solved problem for 
industrialists and academics. In this study, the surface roughness of Scotch pine (Pinus sylvestris) wood was minimized with optimization procedure. Firstly, prediction models were established with ANN method using the data obtained from experimental study. The spindle speed, feed rate, depth of cut and axial depth of cut were optimized to reach minimum surface roughness of wood samples using GA method. The result of optimization procedure, minimum surface roughness was determined $3,8314 \mu \mathrm{m}$ and optimum operating conditions were $1874,5 \mathrm{rad} / \mathrm{s}$ spindle speed, $3,0 \mathrm{~m} / \mathrm{min}$ feed rate, $9,7 \mathrm{~mm}$ depth of cut and 12,0 $\mathrm{mm}$ axial depth of cut.

\section{REFERENCES}

ASTM. 1994. Standard test methods for conducting machining tests of wood and wood-base materials. ASTM. D 1666-87. 1994. ASTM Standards:PA, USA. https://www.astm.org/DATABASE.CART/HISTORICAL/D1666-87R04.htm

Asilturk, I.; Cunkas, M. 2011. Modeling and prediction of surface roughness in turning operations using artificial neural network and multiple regression method. Expert Syst Appl 38(5): 5826-5832. https://doi.org/10.1016/j.eswa.2010.11.041

Bonac, T. 1979. Wood roughness volume and depth estimated from pneumatic surface measurements. Wood Sci 11: 227-232. https://pascal-francis.inist.fr/vibad/index.php?action=getRecordDetail\&idt=PASCAL7960435484

Burdurlu, E.; Usta, I.; Ulupinar, M.; Aksu, B.; Erarslan, T.Ç. 2005. The effect of the number of blades and the grain size of abrasives in planing and sanding on the surface roughness of European black pine and Lombardy poplar. Turk J Agric For 29(4): 315-322. http://journals.tubitak.gov.tr/agriculture/issues/tar-05-294/tar-29-4-11-0403-12.pdf

De Deus, P.R.; de Sampaio Alves, M.C.; Vieira, F.H.A. 2015. The quality of MDF workpieces machined in CNC milling machine in cutting speeds, feedrate, and depth of cut. Meccanica 50(12): 2899-2906. https://doi.org/10.1007/s11012-015-0187-z

DIN. 4768. 1990. Determination of values of surface roughness parameters Ra, Rz, Rmax using electrical contact (Stylus) instruments, Concepts and measuring conditions. Deutsches Institut für Normung: Berlin, Germany. https://infostore.saiglobal.com/en-us/standards/din-4768-e-1990-383197_saig_din_din_870873/

Gawroński, T. 2013. Optimisation of CNC routing operations of wooden furniture parts. Int J Adv Manuf Tech 67(9-12): 2259-2267. https://doi.org/10.1007/s00170-012-4647-5

Haykin, S. 1994. Neural networks: a comprehensive foundation. Prentice Hall PTR: Upper Saddle River, NJ, United States. https://dl.acm.org/doi/book/10.5555/541500

Hazir, E.; Koc, K.H. 2016. Optimization of wood surface machining parameters in CNC routers: Response surface methodology (RSM) approach. Int J Sci Eng Technol 5: 1-8.

Hazir, E.; Koc, K.H. 2018. A modeling study to evaluate the quality of wood surface. Maderas-Cienc Tecnol 20(4): 691-702. http://dx.doi.org/10.4067/S0718-221X2018005041501

Hazir, E.; Koc, K.H. 2019. Optimization of wood machining parameters in CNC routers: Taguchi orthogonal array based simulated angling algorithm. Maderas-Cienc Tecnol 21(4): 493-510. http://dx.doi.org/10.4067/S0718-221X2019005000406

Hazir, E.; Ozcan, T. 2019. Response surface methodology integrated with desirability function and genetic algorithm approach for the optimization of CNC machining parameters. Arab J Sci Eng 44(3): 2795-2809. https://doi.org/10.1007/s13369-018-3559-6

Kant, G.; Sangwan, K.S. 2015. Predictive modelling and optimization of machining parameters to minimize surface roughness using artificial neural network coupled with genetic algorithm. Procedia CIRP 31: 453-458. https://doi.org/10.1016/j.procir.2015.03.043 
Kilic, M.; Hiziroglu, S.; Burdurlu, E. 2006. Effect of machining on surface roughness of wood. Build Environ 41(8): 1074-1078. https://doi.org/10.1016/j.buildenv.2005.05.008

Koc, K.H.; Erdinler, E.S.; Hazir, E.; Ozturk, E. 2017. Effect of CNC application parameters on wooden surface quality. Measurement 107: 12-18. https://doi.org/10.1016/j.measurement.2017.05.001

Kumar, S.L. 2018. Experimental investigations and empirical modeling for optimization of surface roughness and machining time parameters in micro end milling using Genetic Algorithm. Measurement 124: 386-394. https://doi.org/10.1016/j.measurement.2018.04.056

Mirjalili, S. 2015. Moth-flame optimization algorithm: A novel nature-inspired heuristic paradigm. Knowledge-Based Systems 89: 228-249. https://doi.org/10.1016/j.knosys.2015.07.006

Patel, R.D.; Oza, N.V.; Bhavsar, S.N. 2014. Prediction of surface roughness in CNC milling machine by controlling machining parameters using ANN. Int J Mech Eng Robot Res 3(4): 353. http://www.ijmerr.com/ show-129-488-1.html

Peters, C.; Cumming, J.D. 1970. Measuring wood surface smoothness: a review. Forest Prod J 20(12): 40-43. https://www.cabdirect.org/cabdirect/abstract/19706607097

Prakash, S.; Palanikumar, K. 2011. Modeling for prediction of surface roughness in drilling MDF panels using response surface methodology. J Compos Mater 45(16): 1639-1646. https://doi.org/10.1177/0021998310385026

Sofuoglu, S.D. 2015a. Using artificial neural networks to model the surface roughness of massive wooden edge-glued panels made of Scotch pine (Pinus sylvestris L.) in a machining process with computer numerical control. BioResources 10(4): 6797-6808. https://ojs.cnr.ncsu.edu/index.php/BioRes/article/view/ BioRes_10_4_6797_Sofuoglu_Artificial_Neural_Networks_Roughness_Pine/3804

Sofuoglu, S.D. 2015b. Determination of optimal machining parameters of massive wooden edge-glued panels made of European larch (Larix decidua Mill.) using Taguchi design method. BioResources 10(4): 7772-7781. https://ojs.cnr.ncsu.edu/index.php/BioRes/article/view/BioRes_10_4_7772_Sofuoglu_Determination_Optimal_Machining_Parameters/3897

Stanojevic, D.; Mandic, M.; Danon, G.; Svrzic, S. 2017. Prediction of the surface roughness of wood for machining. J For Res 28(6): 1281-1283. https://doi.org/10.1007/s11676-017-0401-z

Sutcu, A. 2013. Investigation of parameters affecting surface roughness in $\mathrm{CNC}$ routing operation on wooden EGP. BioResources 8(1): 795-805. https://ojs.cnr.ncsu.edu/index.php/BioRes/article/view/BioRes_08_1_ Sutcu_795_Parameters_Surface_Roughness/1921

Thoma, H.; Peri, L.; Lato, E. 2015. Evaluation of wood surface roughness depending on species characteristics. Maderas-Cienc Tecnol 17(2): 285-292. http://dx.doi.org/10.4067/S0718-221X2015005000027

Tiryaki, S. 2014. Effecting factors on surface roughness in wood machining. Turkish J For 15(2): 176182. https://dergipark.org.tr/tr/pub/tjf/issue/20903/224498

Tiryaki, S.; Malkocoglu, A.; Ozsahin, S. 2014. Using artificial neural networks for modeling surface roughness of wood in machining process. Constr Build Mater 66: 329-335. https://doi.org/10.1016/j.conbuildmat.2014.05.098_

TS. 2471. 2005. Wood, Determination of Moisture Content for Physical and Mechanical Tests. TS. 2471. 2005. Turkish Standardization Institute: Ankara, Turkey. https://intweb.tse.org.tr/Standard/Standard/Standard. aspx?081118051115108051104119110104055047105102120088111043113104073082090099088118111107 082114112106 